\section{Cucumber Cultivars for Container Gardening and the Value of Field Trials for Predicting Cucumber Performance in Containers}

\author{
Melisa Crane and Todd C. Wehner ${ }^{1}$ \\ Department of Horticultural Science, North Carolina State University, \\ Raleigh, NC 27695-7609
}

Rachel P. Naegele

San Joaquin Valley Agricultural Sciences Center, USDA, Agricultural Research Service, 9611 South Riverbend Avenue, Parlier, CA 93648-9757

Additional index words. Cucumis sativus, Cucurbitaceae, patio, pot gardening, home gardening

\begin{abstract}
Cucumber (Cucumis sativus L.) is one of the most popular vegetable crops grown in U.S. home and urban gardens. The objectives of this study were to identify cultivars and planting densities for high yield of container-grown cucumbers. Additional objectives were to determine the value of field trials for predicting cucumber performance in containers and to evaluate different plant types (dwarf-determinate vs. tallindeterminate, gynoecious vs. monoecious, pickling vs. slicing) for container use and disease severity across cultivars. Fourteen cultivars and breeding lines were tested at three planting densities in two seasons for yield, quality, and disease resistance in field and patio trials. Significant differences were detected for seasons, cultivars, and densities. Yields were highest in the spring season compared with the summer season, and the best performance was obtained using three plants per $12 \mathrm{~L}$ container. There was a high correlation between patio and field trials, allowing extension specialists to recommend cucumber cultivars with high yield, high quality, and disease resistance based on field trial data. Home gardeners who want space-saving, high-yielding cucumbers with tender skin should consider a dwarf-determinate, pickling type that is monoecious. With monoecious type, no pollenizer is needed, and the harvest will be spread over more weeks than would be for gynoecious types.
\end{abstract}

Cucumber (C. sativus L.) is a popular vegetable originating in India (Harlan, 1975), but grown throughout the world for centuries. The main types of cucumbers grown are American pickling, American slicing, Middle Eastern (Beit Alpha), European greenhouse (parthenocarpic), Asian slicer, and Oriental trellis. Cucumber types differ in fruit length, diameter, skin color, color uniformity, skin thickness, and skin surface texture based on their primary use (Wehner, 1989). Most cucumber cultivars have long vines and are grown flat on the ground or on trellis supports (oriental and greenhouse types). Pickling and slicing cucumbers are the two main types grown for commercial markets and home gardens in the United States; annual per capita consumption of fresh and processed cucumber was 2.9 and $2.2 \mathrm{~kg}$, respectively in 2005 (USDA, 2005). In 2014, per capita consumption of fresh cucumbers was $3.1 \mathrm{~kg}$ (Statista GmbH, 2017).

Received for publication 20 Mar. 2017. Accepted for publication 16 Nov. 2017.

We gratefully acknowledge the technical assistance of Tammy L. Ellington.

${ }^{1}$ Corresponding author. E-mail: tcwehner@gmail. com.
Although cucumbers require a large growing area, vines can be trained vertically on a trellis to minimize space. Alternatively, gardeners may choose to grow dwarf, determinate, or compact cucumber cultivars that have shorter vines for patio containers or small garden spaces. These cultivars are sometimes categorized as compact or bush types based on their short internodes. Plant breeders make use of the determinate $(d e)$ gene for the dwarf habit because the bush (bu) and compact ( $c p)$ genes are associated with poor growth or abnormal seeds. Cucumber cultivars with dwarf growth habit include 'Bush Whopper II', 'Picklebush', and 'Bush Champion'. tion of three types of flowers: staminate (male), pistillate (female), and perfect (male and female). Based on the type of flowers present, cucumbers are monoecious (staminate and pistillate flowers), androecious (staminate flowers only), gynoecious (pistillate flowers only), hermaphroditic (perfect flowers only), or andromonoecious (staminate and perfect flowers). Cucumber plants are normally monoecious, but most current commercial cultivars are gynoecious hybrid blends ( $88 \%$ gynoecious plus $12 \%$ monoecious pollenizer) or parthenocarpic (pistillate flowers
Cucumber plants can produce a combina- only, and fruit set without pollination). Gynoecious and parthenocarpic cultivars usually have earlier and more concentrated yield, whereas monoecious cultivars will produce fruit over a longer period of time. An earlier and concentrated production period is preferred by commercial growers and processors, but may not be ideal for home gardeners. In a study conducted by Wehner and Miller (1985), three versions of the hybrid 'Meridian 76' (gynoecious $\times$ gynoecious, gynoecious $\times$ monoecious, and monoecious $x$ monoecious) were similar in overall yield among the hybrids. The gynoecious hybrids provided an advantage in early yield (higher yield at first harvest), but had more grade No. 2 and cull fruit than the monoecious hybrid, possibly because of the high number of pistillate flowers pollinated and grown in a tight sequence.

Urban and container gardening are two of the fastest growing gardening trends in the United States (Crandall and Crandall, 1996; Mason et al., 2008). Urban gardening can occur at the individual or community level, stimulating economic development, creating green space, and providing a source of fresh vegetables, fruits, and flowers for local communities. Urban gardens have a beneficial effect on communities, and cities are starting to include these spaces in city planning (Colasanti et al., 2012; Freeman et al., 2012; Hunter and Brown, 2012). In addition to community gardens, container gardens provide a convenient alternative for the home-production of vegetables, fruits, and flowers. As the number of people living in apartments, condominiums, and townhouses increases, so does the number of potential container gardeners.

Despite the popularity of container gardening, information is limited on cultivars and optimal production methods for container-grown vegetable production. Internet resources are plentiful, but might not be based on scientific research. Universities continuously update their extension bulletins and services, but without home gardening studies they have been unable to make research-based recommendations. One such bulletin recommended the use of cultivar H-19 littleleaf, a tall, multibranched inbred with late maturity (Hopkins et al., 2008). This pure-line cultivar does have multiple branching and high yield, but its concentrated set makes it less appealing for many home gardeners. 'Bush Champion' is another popular cultivar recommended by extension specialists. In older (pre 2005) resources, many of the recommended cultivars have growth habits unsuited to container production or are no longer available. Also, the cultural practices in the literature are often vague and recommend various cultivars, container sizes, media types, fertilizer, and water regimes. One would hope that they were based on local production requirements.

In addition to limited information on production practices, plant diseases can be a hindrance for urban gardeners. Because of space constraints, home gardeners often use higher 
plant densities than university or commercial recommendations. Increased plant densities promote disease development. With the available chemical control options, there is a need for high yielding, dwarf, and resistant cultivars for urban gardens. Heirloom cultivars often lack disease resistance, and commercial cultivars with resistance may be unavailable. Two common diseases of cucumber are powdery mildew (PM) and downy mildew (DM) (Adams and QuesadaOcampo, 2015; Ojiambo et al., 2015). These diseases often appear in mid- to late summer and affect the leaves of the plant. Powdery mildew, caused by Podosphaera xanthii, produces chlorotic spots on the upper leaf surface with an eventual white "powdery" appearance as the disease progresses. Downy mildew, caused by Pseudoperonospora cubensis, causes angular chlorotic lesions on the upper leaf surface (Ojiambo et al., 2015). Both pathogens can significantly reduce yield and fruit quality in field- or container-grown plants.

In urban gardening, container size is also an important factor. Cucumber roots grow 30-60 cm deep in field soil (Sanders, 1997). Inadequately sized containers result in small plants and may reduce fruit quality and yield. In addition, small containers can dry out rapidly, resulting in poor nutrient uptake, stressed plants, and reduced yield. Large containers are often preferred, but can be difficult to move and require a large amount of potting media. Various container sizes are recommended in extension publications from U.S. universities, including a 20-40 L container with one to two plants each (Crandall and Crandall, 1996), an 8-20 L container or hanging basket (Harrison, 1996), a container with one plant per $4 \mathrm{~L}$ of soil volume (Bass, 1999), a larger container for vining crops (including tall-indeterminate cucumber) than crops with bush habit with 16-20 L of potting medium per plant (Demboski et al., 2001) and 12-20 L per plant (Hopkins et al., 2008; Whiting et al., 2014).

The objectives of this study were to 1) determine the optimal cucumber cultivars of several types (dwarf vs. tall, gynoecious vs. monoecious, pickling vs. slicing) and planting density for use in containers and 2) evaluate field trials as a predictor of cultivar performance in containers.

\section{Materials and Methods}

Experiments were conducted at the Horticultural Crops Research Station in Clinton, $\mathrm{NC}$, during the spring (May-July) and summer (August-September) seasons in a single year. Twelve commercial cultivars were evaluated based on NC extension recommendations for field and for container production representing different plant types (monoecious, gynoecious, tall, dwarf, pickling, and slicing) (Table 1). One container garden cultivar, M $27 \times \mathrm{NC}-25$, which had not been released at the time of planting, was also included. Greenhouse and trellis cucumbers were excluded from this trial. Greenhouse cucumbers should be grown in structures that exclude insects as they have bitterfree foliage and parthenocarpic fruit, and both types must be supported to prevent a large proportion of their fruit from curving (common with fruit longer than $300 \mathrm{~mm}$ ).

For container evaluations, $12 \mathrm{~L}$ pots were filled with a soilless medium (Metro Mix 360). Cucumbers were direct seeded into containers and thinned to desired density. Three planting densities (12 L of soil/plant, $6 \mathrm{~L}$ of soil/plant, and $4 \mathrm{~L}$ of soil/plant) were evaluated. Plots consisted of a single container of one, two, or three plants each, set on raised, shaped beds in the field (Fig. 1.). Beds were covered with black plastic to simulate containers on a paved surface. Containers were spaced $1.5 \mathrm{~m}$ apart in the row, with rows $45 \mathrm{~m}$ long. Row centers were $1.5 \mathrm{~m}$ apart, with a total of nine rows. Irrigation was set up to water for $1 \mathrm{~h} \cdot \mathrm{d}^{-1}$ in the morning in addition to rain events. Spray emitters were used with a flow rate of $12 \mathrm{~L} \cdot \mathrm{h}^{-1}$. A liquid fertilizer (Peters 20-20-20) was added through the drip line daily. Plants were not treated with fungicide or insecticides and were exposed to natural levels of PM and DM inoculum.

The spring patio trial was planted on 9 May and thinned on 19 May to one, two, or three plants to provide the desired planting density. Cucumber plants were evaluated for flower type on 23 June. Gynoecious ratings were based on a visual 1 to 9 scale $(1=$ androecious, 2 to 3 = andromonoecious, 4 to $6=$ monoecious, 7 to $8=$ predominately gynoecious, 9 = gynoecious). Vine length (VL), as the maximum length of the main vine, was measured at harvest 1 on 23 June and at harvest 8 on 18 July. A disease rating for PM was recorded on 14 July. Disease ratings were based on a 0 to 9 scale where $0=$ no disease, 1 to $2=$ trace, 3 to $4=$ slight, 5 to $6=$ moderate, 7 to $8=$ severe, and $9=$ plant dead. The trial was harvested twice a week for a total of eight harvests. All fruit larger than 25-mm diameter were harvested and weight of marketable and cull fruit of each plot were recorded.

For the summer trial, seeds were planted in the greenhouse at the Horticulture Field Laboratory in Raleigh, NC, in 72 cell trays (Hummert Intl., St. Joseph, MO). One week after planting, seedlings were placed into a coldframe at the Clinton Research Station to harden off. The patio containers were transplanted on 11 Aug. Sex expression was rated on 24 Aug. Vine length was measured at harvest 1 on 18 Aug. and at harvest 8 on 15 Sept. A disease rating for DM was recorded on 15 Sept.

The experiment was a randomized complete block with 2 seasons (spring and summer), 14 cultigens (breeding lines and cultivars), 3 plant densities (one, two, or three plants per container), and 6 replications. For both the spring and summer container trials, corresponding field trials were run for comparison.

Field trials were direct seeded into raised beds covered with black polyethylene mulch and grown according to the North Carolina
Extension Service and Southeastern US 2009 Vegetable Crops handbook recommendations (Holmes and Kemble, 2009; Sanders, 2004). The experiment was a randomized complete block design with 2 seasons, 14 cultigens, 3 replications, and 6 harvests (eight for the pickling cucumbers). The soil was an Orangeburg loamy sand (Fine-loamy, kaolinitic, thermic Typic Kandiudults). Plants were established by direct seeding into raised beds. Plots were single $6.1 \mathrm{~m}$ rows with $1.5 \mathrm{~m}$ alleys at each end. Beds were $1.5 \mathrm{~m}$ apart (center to center). Fertilizer consisted of 90-39-74 kg.ha ${ }^{-1}(\mathrm{~N}-\mathrm{P}-\mathrm{K})$ broadcast preplant and $34-0-0 \mathrm{~kg} \cdot \mathrm{ha}^{-1}(\mathrm{~N}-\mathrm{P}-\mathrm{K})$ side dressed at the two to four leaf stage. Curbit (active ingredient Ethalfluralin) (Loveland Products, Inc., Loveland, CO) was applied preemergence at the rate of $0.4 \mathrm{~kg}$ a.i./A. The plots were irrigated as needed for a total of 25-40 mm.week ${ }^{-1}$. Downy mildew was controlled by Previcur Flex (active ingredient Propamocarb hydrochloride) alternated with Tanos (active ingredient Famoxadone and Cymoxanil) beginning at the two true leaf stage.

Field plots were direct-seeded and thinned to 60 plants per plot. Dates for planting, thinning, and data collection in the field plots were the same as for the patio trials. Pickling cucumber trials were harvested eight times, twice per week. Fruit were weighed after sorting by diameter into No. 1 (0-26 mm), No. 2 (27-38 mm), No. 3 (39-51 mm), oversize, and cull (nubbins and crookeds) grades according to the recommendation of the North Carolina Pickle Producers Association (industry standard). Slicing cucumber trials were harvested six times, twice per week. Fruit were weighed after sorting by quality into Fancy, No. 1, No. 2 , and cull grades according to U.S. Department of Agriculture (USDA) standards (USDA, 2016).

Fruit from patio and field trials were evaluated for shape rating, color rating, seedcell size rating, overall quality rating, length, length/diameter ratio (LD ratio), and firmness (pickling types only). Ratings for shape, color, seedcell, and overall quality were based on a 1 to 9 scale ( 1 to $3=$ poor, 4 to $6=$ intermediate, 7 to $9=$ excellent). Firmness was measured on three No. 3 grade fruit using a Magness-Taylor tester with an $8 \mathrm{~mm}$ tip. LD ratio was calculated by measuring five No. 2 grade fruit. Slicer fruit length, diameter, and weight were recorded for three Fancy grade fruit per plot. Overall, quality was judged on all quality traits including shape, color, and seedcell.

Average monthly temperature and rainfall data were collected from the NC Climate Retrieval and Observations Network of the Southeast database (CRONOS) system (climate. ncsu.edu/cronos). Daily weather data were recorded at the Horticultural Crops Research Station using an ECONET tower maintained by the State Climate Office of North Carolina. Monthly temperature and rainfall averages were calculated directly through CRONOS. 
Statistical analyses were conducted using the PROC MEANS, CORR, and GLM procedures of SAS statistical software package (SAS Institute, 2005). Traits evaluated included total yield (sum of harvests 1-8), early yield (sum of harvests 1-3), percentage marketable fruit, VL (harvests 1 and 8), gynoecious rating, PM rating (spring), and DM rating (summer).

\section{Results}

Significant differences were detected in the patio trial in plant characteristics, yield, and disease ratings among cultivars, planting densities, seasons, and replicates. Season had a significant effect for total $(P=0.0001)$, marketable $(P=0.044)$, and cull $(P=0.0001)$ yield across all eight harvests; total $(P=$ $0.0001)$, marketable $(P=0.0001)$, and cull $(P=0.0103)$ for early yield (harvests $1-3)$; percentage marketable fruit $(P=0.001)$; and VL at harvest $1(P=0.0001)$ and 8 $(P=0.0026)$. Spring and summer seasons were analyzed separately for remaining analyses. When analyzed by season, cultivar was significant for every trait: total yield, early yield, percentage marketable fruit, VL at harvest $1, \mathrm{VL}$ at harvest 8, gynoecious rating, $\mathrm{PM}$ rating, and DM rating. Planting density had a significant effect on total, marketable, and cull yield across all seven harvests, percentage marketable fruit, total and marketable early yield, and VL at harvests 1 and 8 in the spring season (Table 2). Planting density and its interaction with cultivar was not significant. During the summer season, planting density did not significantly affect
VL (harvests 1 or 8 ), total early harvest, total and early marketable yield, total cull yield, gynoecious rating, or the percentage marketable fruit. Planting density did not significantly affect disease ratings for DM (summer season) or PM (spring season). During the summer season, there were not significant cultivar by planting density interactions for

Table 1. General characteristics of the 14 cucumber cultigens evaluated for growth in containers in two locations in North Carolina.

\begin{tabular}{llll}
\hline Cultigen & Vine type & Type & Sex expression \\
\hline Slicing types & & & \\
Dasher II & Tall & Hybrid & Gynoecious \\
Marketmore 76 & Tall & Inbred & Monoecious \\
Spacemaster & Dwarf & Inbred & Gynoecious \\
Bush Champion & Dwarf & Inbred & Monoecious \\
Bush Whopper II & Dwarf & Hybrid & Monoecious \\
Cherokee & Tall & Hybrid & Gynoecious \\
Pickling types & Tall & Hybrid & Gynoecious \\
Vlaspik & Tall & Hybrid & Monoecious \\
NC-Danbury & Dwarf & Inbred & Monoecious \\
NC-25 & Dwarf & Inbred & Monoecious \\
M 27 & Tall & Inbred & Monoecious \\
NC-74 & Dwarf & Hybrid & Monoecious \\
M $27 \times$ NC-25 & Dwarf & Inbred & Monoecious \\
Picklebush & Tall & Inbred & Monoecious \\
Sumter & Tym
\end{tabular}

Gynoecious has only pistillate flowers on the plant; monoecious has staminate followed by pistillate flowers.

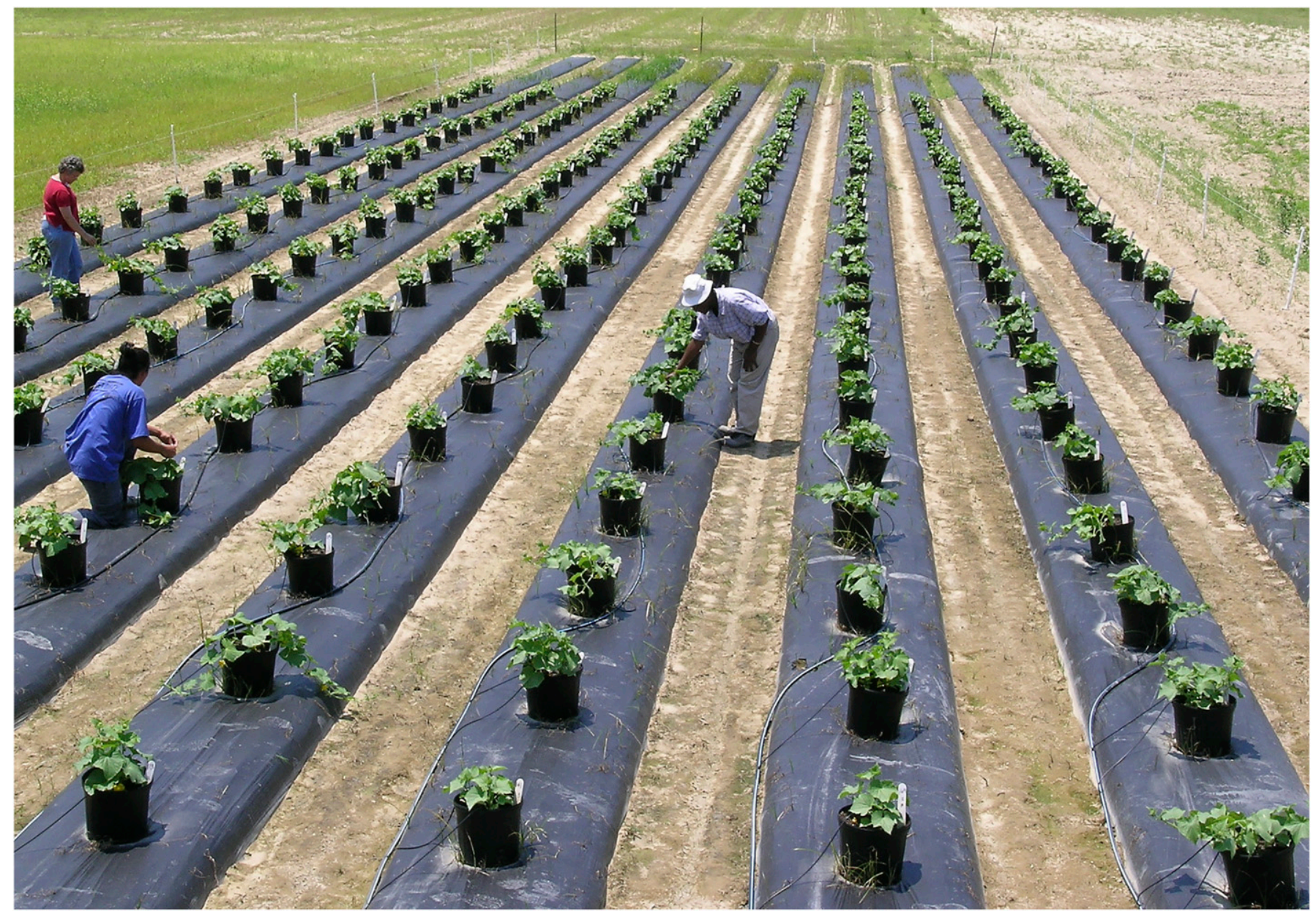

Fig. 1. Patio cucumber trial using containers on a plastic mulch and drip irrigation at Horticultural Crops Research Station, Clinton, paired with field trial in the same location (not shown). 
Table 2. Fruit yield and vine data for 14 cultivars, 3 densities, and 2 seasons tested in patio containers in North Carolina.

\begin{tabular}{|c|c|c|c|c|c|c|c|c|c|c|c|c|c|}
\hline \multirow[b]{3}{*}{ Cultigen } & \multirow{3}{*}{$\begin{array}{c}\text { Density } \\
\text { (plants/pot) }\end{array}$} & \multicolumn{6}{|c|}{ Yield } & \multirow{2}{*}{\multicolumn{2}{|c|}{$\begin{array}{l}\text { Vine length } \\
\text { H1 }(\mathrm{mm})^{\mathrm{z}}\end{array}$}} & \multirow{2}{*}{\multicolumn{2}{|c|}{$\begin{array}{l}\text { Vine length } \\
\text { H8 }(\mathrm{mm})^{\mathrm{y}}\end{array}$}} & \multirow{2}{*}{\multicolumn{2}{|c|}{$\begin{array}{l}\text { Gynoecious } \\
\text { rating }(1 \text { to } 9)^{\mathrm{x}}\end{array}$}} \\
\hline & & \multicolumn{2}{|c|}{ Total (g/pot) } & \multicolumn{2}{|c|}{ Early (g/pot) } & \multicolumn{2}{|c|}{ Marketable (\%) } & & & & & & \\
\hline & & $\mathrm{Sp}^{\mathrm{w}}$ & $\mathrm{Sm}^{\mathrm{v}}$ & $\mathrm{Sp}$ & $\mathrm{Sm}$ & $\mathrm{Sp}$ & $\mathrm{Sm}$ & $\mathrm{Sp}$ & $\mathrm{Sm}$ & $\mathrm{Sp}$ & $\mathrm{Sm}$ & $\mathrm{Sp}$ & $\mathrm{Sm}$ \\
\hline \multirow[t]{3}{*}{$\mathrm{Bu} \mathrm{Ch}^{\mathrm{u}}$} & 1 & 1,572 & 136 & 386 & 34 & 80 & 8 & 515 & 331 & 948 & 646 & 3.5 & 4.3 \\
\hline & 2 & 3,001 & 181 & 446 & 45 & 79 & 0 & 523 & 313 & 823 & 606 & 4.3 & 3.5 \\
\hline & 3 & 2,253 & 91 & 401 & - & 80 & 0 & 442 & 280 & 782 & 613 & 3.5 & 3.5 \\
\hline \multirow[t]{3}{*}{$\mathrm{Bu} \mathrm{Wh} \mathrm{IIt}$} & 1 & 1,769 & 726 & 257 & 218 & 85 & 73 & 513 & 454 & 974 & 1,016 & 3.7 & 4.6 \\
\hline & 2 & 1,837 & 711 & 189 & 189 & 84 & 58 & 492 & 402 & 1,006 & 1,014 & 4.0 & 4.5 \\
\hline & 3 & 1,996 & 688 & 378 & 189 & 93 & 73 & 450 & 479 & 917 & 903 & 4.3 & 5.0 \\
\hline \multirow[t]{3}{*}{ Cherokee7 } & 1 & 1,981 & 835 & 696 & 318 & 73 & 38 & 832 & 541 & 1,134 & 904 & 7.0 & 7.2 \\
\hline & 2 & 2,752 & 1,089 & 794 & 372 & 72 & 56 & 810 & 569 & 1,244 & 1,304 & 5.5 & 6.3 \\
\hline & 3 & 2,661 & 896 & 771 & 408 & 78 & 68 & 697 & 548 & 1,052 & 1,085 & 5.8 & 5.8 \\
\hline \multirow[t]{3}{*}{ Dasher II } & 1 & 2,253 & 703 & 816 & 159 & 79 & 78 & 868 & 598 & 1,065 & 1,380 & 8.0 & 6.7 \\
\hline & 2 & 2,419 & 826 & 847 & 91 & 76 & 71 & 865 & 511 & 1,307 & 1,252 & 9.0 & 5.4 \\
\hline & 3 & 2,555 & 998 & 794 & 287 & 80 & 72 & 713 & 572 & 1,048 & 972 & 7.0 & 7.3 \\
\hline \multirow[t]{3}{*}{$\mathrm{NC}-25$} & 1 & 1,754 & 839 & 499 & 408 & 93 & 51 & 512 & 288 & 701 & 413 & 3.7 & 5.8 \\
\hline & 2 & 1,557 & 1,134 & 454 & 476 & 93 & 76 & 465 & 275 & 652 & 475 & 4.8 & 4.0 \\
\hline & 3 & 1,671 & 896 & 552 & 374 & 85 & 64 & 395 & 323 & 566 & 463 & 3.8 & 5.3 \\
\hline \multirow[t]{3}{*}{ M 27} & 1 & 1,497 & 544 & 242 & 272 & 85 & 75 & 418 & 505 & 603 & 1,105 & 3.7 & 5.3 \\
\hline & 2 & 1,633 & 560 & 423 & 243 & 80 & 58 & 397 & 445 & 623 & 903 & 3.8 & 5.2 \\
\hline & 3 & 1,792 & 688 & 348 & 265 & 82 & 60 & 335 & 487 & 598 & 970 & 4.3 & 4.0 \\
\hline \multirow[t]{3}{*}{$\mathrm{MM} 76^{\mathrm{s}}$} & 1 & 2,132 & 696 & 333 & 136 & 95 & 84 & 735 & 523 & 1,221 & 1,072 & 4.2 & 4.7 \\
\hline & 2 & 2,011 & - & 438 & - & 89 & - & 638 & - & 1,123 & - & 4.3 & - \\
\hline & 3 & 2,344 & 786 & 401 & 83 & 90 & 88 & 555 & 438 & 1,046 & 1,137 & 5.2 & 4.0 \\
\hline \multirow[t]{3}{*}{ NC-74 } & 1 & 1,678 & 692 & 499 & 261 & 94 & 73 & 842 & 471 & 1,243 & 831 & 3.8 & 4.8 \\
\hline & 2 & 1,671 & 567 & 499 & 249 & 95 & 81 & 787 & 526 & 998 & 978 & 3.7 & 4.8 \\
\hline & 3 & 2,397 & 517 & 650 & 145 & 93 & 90 & 733 & 415 & 1,087 & 968 & 3.8 & 4.4 \\
\hline \multirow[t]{3}{*}{ NC-Danbury } & 1 & 1,814 & 862 & 272 & 345 & 87 & 57 & 555 & 441 & 1,103 & 808 & 3.7 & 6.4 \\
\hline & 2 & 1,996 & 1,168 & 461 & 386 & 96 & 83 & 545 & 481 & 999 & 989 & 4.0 & 6 \\
\hline & 3 & 2,321 & 1,278 & 461 & 408 & 91 & 81 & 545 & 467 & 993 & 954 & 3.7 & 5.7 \\
\hline \multirow[t]{3}{*}{ M $27 \times \mathrm{NC}-25$} & 1 & 1,497 & 653 & 575 & 318 & 92 & 55 & 735 & 546 & 1,036 & 898 & 3.2 & 6.4 \\
\hline & 2 & 1,973 & 567 & 635 & 219 & 91 & 57 & 732 & 443 & 932 & 687 & 3.7 & 4.3 \\
\hline & 3 & 2,404 & 816 & 507 & 370 & 91 & 59 & 670 & 528 & 895 & 940 & 3.7 & 5.5 \\
\hline Picklebush & 1 & 1,482 & 408 & 582 & 191 & 87 & 60 & 382 & 257 & 538 & 368 & 3.7 & 4 \\
\hline & 2 & 2,003 & 544 & 620 & 257 & 90 & 36 & 377 & 290 & 529 & 367 & 3.7 & 3.7 \\
\hline & 3 & 2,593 & 575 & 764 & 249 & 88 & 37 & 392 & 261 & 539 & 372 & 3.8 & 4.2 \\
\hline Spacem $^{r}$ & 1 & 2,208 & 381 & 612 & 109 & 71 & 43 & 622 & 385 & 965 & 774 & 7.7 & 4.8 \\
\hline & 2 & 2,510 & 257 & 711 & 53 & 73 & 6 & 567 & 373 & 870 & 828 & 7.5 & 5.5 \\
\hline & 3 & 3,047 & 181 & 756 & 45 & 83 & 6 & 520 & 305 & 993 & 794 & 7.5 & 5 \\
\hline Sumter & 1 & 1,399 & 559 & 537 & 257 & 92 & 61 & 905 & 587 & 1,259 & 1,156 & 4.0 & 5.2 \\
\hline & 2 & 1,822 & 572 & 582 & 191 & 90 & 40 & 875 & 558 & 1,025 & 948 & 4.0 & 4.8 \\
\hline & 3 & 2,011 & 801 & 688 & 325 & 86 & 58 & 773 & 549 & 1,055 & 1,070 & 3.5 & 4.3 \\
\hline Vlaspik & 1 & 2,071 & 964 & 786 & 442 & 87 & 74 & 612 & 500 & 897 & 936 & 9.0 & 6.5 \\
\hline & 2 & 1,996 & 771 & 862 & 325 & 91 & 79 & 483 & 427 & 652 & 762 & 9.0 & 6.2 \\
\hline & 3 & 2,820 & 1,198 & 885 & 535 & 95 & 70 & 480 & 468 & 775 & 762 & 8.2 & 7.8 \\
\hline LSD $(5 \%)$ & - & 586 & 253 & 199 & 153 & 9 & 20 & 100 & 112 & 156 & 174 & 1.4 & 1.3 \\
\hline
\end{tabular}

LSD $=$ least significant difference.

${ }^{\mathrm{z}}$ Vine length in $\mathrm{mm}$ at harvest 1.

${ }^{\mathrm{y}}$ Vine length in $\mathrm{mm}$ at harvest 8.

${ }^{\mathrm{x}}$ Gynoecious rating ( 1 to $9,1=$ androecious, 5 = monoecious, $9=$ gynoecious $)$.

${ }^{\mathrm{w}}$ Spring season.

${ }^{\mathrm{v}}$ Summer season.

${ }^{\mathrm{u} C u l t i v a r}$ Bush champion.

${ }^{\mathrm{t} C u l t i v a r}$ Bush Whopper.

${ }^{\mathrm{s} C u l t i v a r}$ Marketmore 76.

${ }^{\mathrm{r}}$ Cultivar Spacemaster.

any of the traits evaluated with the exception of VL at harvest 8.

In this study, large differences were observed in cultivar performance between spring and fall seasons. Cultivars performed best in the spring season with an average yield 300\% higher than the summer season (Table 2). Temperature during the spring season ranged from 24.2 to $30.4{ }^{\circ} \mathrm{C}$ for the maximum daily temperature and 9.4 to $23.2{ }^{\circ} \mathrm{C}$ for the minimum daily temperature compared with 26.6 to $29.8{ }^{\circ} \mathrm{C}$ and 19.8 to $22.7{ }^{\circ} \mathrm{C}$ for the maximum and minimum temperatures, respectively, in the summer season (Table 3). Planting density had a significant effect on yield, with the highest yield

Table 3. Monthly temperature $\left({ }^{\circ} \mathrm{C}\right)$ and precipitation $(\mathrm{cm})$ means, Clinton, NC.

\begin{tabular}{lcccc}
\hline Month & Maximum temp & Minimum temp & Avg temp & Total precipitation \\
\hline May & 24.2 & 9.4 & 18.5 & 8.94 \\
June & 28.3 & 17.8 & 23.9 & 12.6 \\
July & 30.4 & 23.3 & 26.6 & 14.15 \\
August & 29.8 & 22.7 & 26.0 & 9.83 \\
September & 26.6 & 19.8 & 23.9 & 6.17 \\
\hline
\end{tabular}

at three plants/container for only some of the cultivars evaluated (Table 2). Vine length was significantly shorter at the highest planting density. Of the cultivars tested, highest yielders were Cherokee, Dasher II, Marketmore 76, NC-Danbury, Spacemaster, and Vlaspik. The cultivars with the earliest yield were Cherokee, Dasher II, and Vlaspik.
Those with the highest percentage of marketable fruit were 'NC-Danbury', 'NC-25', 'Marketmore 76', 'NC-74', and 'Vlaspik'. The most gynoecious were 'Dasher II' and 'Vlaspik'. Cultivars with longest vine at harvest 8 were Cherokee, Dasher II, Marketmore 76, and Sumter, and with the shortest vine was Picklebush. 
Four of the top six yielding cucumbers ('Cherokee', 'Dasher II', 'Marketmore 76', and 'Spacemaster') and two of the top three early yielding cultivars were slicing types (Cherokee and Dasher II). Those cucumbers with the highest percentage marketable fruit were 'Marketmore 76' (slicing type), and 'NC-Danbury', 'NC-25', 'NC-74', and 'Vlaspik' (pickling type). Cultivars with the highest gynoecious rating were Dasher II slicer and Vlaspik pickler. 'Bush Champion' and 'Spacemaster' (slicing type) and 'Picklebush' (pickling type) were the most susceptible to PM. All pickling cucumbers evaluated in this study were resistant to DM except 'M 27' and 'Picklebush', and all slicing cucumbers were resistant except
'Spacemaster' and 'Bush Champion'. The three gynoecious cucumbers 'Vlaspik', 'Dasher II', and 'Cherokee' (Table 2) were also the three highest early yielders (Table 5). The cultivars most susceptible to PM (spring season only) were Bush Champion, Picklebush, and Spacemaster. The cultivars most susceptible to DM (summer season only) were Bush Champion, M 27, Picklebush, and Spacemaster (Table 5).

Means of fruit quality traits in field trials [shape, color, seedcell size, overall quality, length, LD ratio, and firmness (pickling types only)] across both seasons were used to determine the cultivars with the best overall quality (Table 4). The highest quality pickling types were 'NC-Danbury', NC-74,
'Sumter', M $27 \times$ NC-25 (not a cultivar), 'Vlaspik', and NC-25. The highest quality slicing types were 'Marketmore 76', 'Bush Champion' and 'Dasher II'. The largest LD ratio pickling types were 'Vlaspik' and 'NC-25', 'Sumter', and 'NC-Danbury'. The smallest LD ratio pickling types were 'Picklebush', M $27 \times \mathrm{NC}-25, \mathrm{M} \mathrm{27}$, and NC-74. The largest LD ratio slicing types were 'Bush Whopper II', 'Cherokee', and 'Spacemaster'. The smallest LD ratio slicing types were 'Bush Champion' and 'Dasher II'. The firmest cultivars were Sumter, NC-Danbury, NC-74, M $27 \times$ NC-25, and Vlaspik.

Correlations between patio and field trials for sex expression and fruit yield (Table 5), and for vine and disease traits (Table 6) were

Table 4. Mean fruit quality for 14 cultivars and two seasons tested in field plots in Clinton, NC.

\begin{tabular}{|c|c|c|c|c|c|c|c|c|c|c|c|c|c|c|c|c|c|}
\hline \multirow[b]{2}{*}{ Line } & \multirow[b]{2}{*}{ Overall mean } & \multicolumn{2}{|c|}{ Mean } & \multicolumn{2}{|c|}{ Fruit shape } & \multicolumn{2}{|c|}{ Fruit color } & \multicolumn{2}{|c|}{ Seedcell } & \multicolumn{2}{|c|}{ Overall quality } & \multicolumn{2}{|c|}{ Fruit length } & \multicolumn{2}{|c|}{ Fruit L/D } & \multicolumn{2}{|c|}{ Fruit firmness } \\
\hline & & $\mathrm{Sp}$ & $\mathrm{Sm}$ & $\mathrm{Sp}$ & $\mathrm{Sm}$ & $\mathrm{Sp}$ & $\mathrm{Sm}$ & $\mathrm{Sp}$ & $\mathrm{Sm}$ & $\mathrm{Sp}$ & $\mathrm{Sm}$ & $\mathrm{Sp}$ & $\mathrm{Sm}$ & $\mathrm{Sp}$ & $\mathrm{Sm}$ & $\mathrm{Sp}$ & $\mathrm{Sm}$ \\
\hline \multicolumn{18}{|l|}{ Pickling type } \\
\hline NC-Danbury ${ }^{z}$ & 7.4 & 7.0 & 7.8 & 7.3 & 8.3 & 7.3 & 8.0 & 6.3 & 7.0 & 7.3 & 8.0 & 6.5 & 6.8 & 3.3 & 3.4 & 67 & 71 \\
\hline $\mathrm{NC}-74$ & 7.3 & 7.4 & 7.2 & 7.7 & 8.0 & 7.7 & 7.0 & 7.3 & 7.3 & 7.3 & 6.3 & 6.0 & 5.5 & 3.0 & 2.7 & 71 & 76 \\
\hline M $27 \times \mathrm{NC}-25$ & 7.1 & 7.1 & 7.1 & 7.3 & 7.3 & 7.3 & 7.0 & 6.7 & 7.0 & 7.3 & 7.0 & 6.4 & 5.7 & 3.2 & 2.8 & 67 & 67 \\
\hline Vlaspik & 6.9 & 6.8 & 7.0 & 7.3 & 7.0 & 8.0 & 7.3 & 5.7 & 6.7 & 7.3 & 7.3 & 7.0 & 6.5 & 3.5 & 3.3 & 76 & 71 \\
\hline $\mathrm{NC}-25$ & 6.8 & 7.1 & 6.4 & 7.3 & 6.7 & 7.3 & 7.3 & 6.7 & 5.7 & 7.3 & 7.0 & 7.6 & 6.6 & 3.8 & 3.3 & 62 & 58 \\
\hline Sumter & 6.5 & 7.2 & 5.7 & 7.3 & 5.7 & 5.3 & 5.0 & 7.3 & 6.3 & 7.0 & 5.0 & 6.3 & 6.2 & 3.1 & 3.1 & 85 & 71 \\
\hline M 27 & 5.7 & 6.3 & 5.1 & 7.0 & 5.3 & 5.3 & 5.0 & 5.7 & 5.3 & 6.3 & 4.7 & 6.4 & 5.4 & 3.2 & 2.7 & 67 & 58 \\
\hline Picklebush & 5.2 & 5.7 & 4.6 & 6.3 & 4.7 & 4.0 & 4.0 & 5.3 & 5.0 & 5.3 & 4.0 & 5.8 & 5.8 & 2.9 & 2.9 & 67 & 62 \\
\hline LSD $(5 \%)$ & 1.1 & 1.2 & 1.0 & 1.3 & 1.3 & 0.9 & 1.1 & 1.8 & 1.4 & 1.2 & 1.3 & 0.7 & 0.6 & 0.3 & 0.3 & 12 & 10 \\
\hline \multicolumn{18}{|l|}{ Slicing type } \\
\hline Marketmore 76 & 6.6 & 6.9 & 6.3 & 7.3 & 5.0 & 8.0 & 6 & 6.7 & 8.0 & 6.7 & 6.0 & 6.9 & 7.5 & 3.7 & 3.9 & - & - \\
\hline Bush Champion & 6.6 & 6.1 & 7.0 & 6.0 & 6.7 & 6.0 & 6.7 & 6.3 & 7.3 & 6.0 & 7.0 & 9.1 & 8.2 & 3.5 & 3.8 & - & - \\
\hline Dasher II & 6.3 & 6.7 & 5.9 & 7.0 & 5.3 & 8.0 & 6.7 & 5.7 & 6.3 & 7.3 & 6.0 & 8.1 & 7.3 & 3.6 & 3.3 & - & - \\
\hline Spacemaster & 5.4 & 5.6 & 5.1 & 5.3 & 4.3 & 8.0 & 6.7 & 6.0 & 6.3 & 5.3 & 4.7 & 7.7 & 6.7 & 3.9 & 4.8 & - & - \\
\hline Cherokee & 5.1 & 5.7 & 4.4 & 6.3 & 4.3 & 6.0 & 5.3 & 4.7 & 5.0 & 6.0 & 4.0 & 7.6 & 6.9 & 4.4 & 3.5 & - & - \\
\hline Bush Whopper II & 3.7 & 7.3 & - & 7.0 & - & 9.0 & - & 8.0 & - & 7.0 & - & 9.1 & - & 4.5 & - & - & - \\
\hline $\operatorname{LSD}(5 \%)$ & 1.1 & 1.1 & 1 & 1.4 & 1.4 & 1.1 & 1.4 & 1.5 & 1.3 & 1.4 & 1.2 & 0.9 & 0.7 & 0.4 & 0.3 & - & - \\
\hline
\end{tabular}

LSD $=$ least significant difference.

${ }^{\mathrm{z}}$ Data are means of three replications summed over six harvests (eight harvests for the pickle trials). Mean quality is the average of shape, color, seedcell, and overall quality.

Table 5. Vine lengths and disease resistance for spring and summer patio and field trials for 14 cucumber cultivars.

\begin{tabular}{|c|c|c|c|c|c|c|c|c|c|c|c|c|c|c|c|c|}
\hline & \multicolumn{4}{|c|}{ Vine length $(\mathrm{mm}) \mathrm{H} 1^{\mathrm{z}}$} & \multicolumn{4}{|c|}{ Vine length $(\mathrm{mm}) \mathrm{H}^{\mathrm{y}}$} & \multicolumn{4}{|c|}{ Powdery mildew } & \multicolumn{4}{|c|}{ Downy mildew } \\
\hline & \multicolumn{2}{|c|}{ Spring } & \multicolumn{2}{|c|}{ Summer } & \multicolumn{2}{|c|}{ Spring } & \multicolumn{2}{|c|}{ Summer } & \multicolumn{2}{|c|}{ Spring } & \multicolumn{2}{|c|}{ Summer } & \multicolumn{2}{|c|}{ Spring } & \multicolumn{2}{|c|}{ Summer } \\
\hline & $P^{\mathrm{x}}$ & $F^{\mathrm{W}}$ & $P$ & $F$ & $P$ & $F$ & $P$ & $F$ & $P$ & $F$ & $P$ & $F$ & $P$ & $F$ & $P$ & $F$ \\
\hline \multicolumn{17}{|l|}{ Pickling type } \\
\hline Sumter & 773 & 1,055 & 549 & 1,070 & 750 & 975 & 885 & 1,028 & 1.0 & 2.0 & - & - & - & - & 3.8 & 6.0 \\
\hline $\mathrm{NC}-74$ & 733 & 1,087 & 415 & 968 & 633 & 1,003 & 753 & 1,131 & 1.0 & 2.0 & - & - & - & - & 4.8 & 5.0 \\
\hline NC-Danbury & 545 & 993 & 467 & 954 & 623 & 970 & 800 & 1,030 & 1.3 & 1.0 & - & - & - & - & 3.5 & 4.0 \\
\hline Vlaspik & 480 & 775 & 468 & 762 & 577 & 915 & 753 & 980 & 1.0 & 1.0 & - & - & - & - & 3.8 & 5.0 \\
\hline M $27 \times \mathrm{NC}-25$ & 670 & 895 & 528 & 940 & 527 & 883 & 843 & 1,007 & 1.0 & 2.0 & - & - & - & - & 4.2 & 5.0 \\
\hline $\mathrm{NC}-25$ & 395 & 566 & 323 & 463 & 413 & 690 & 723 & 737 & 1.0 & 1.0 & - & - & - & - & 2.8 & 4.0 \\
\hline Picklebush & 392 & 539 & 261 & 372 & 370 & 670 & 430 & 453 & 6.2 & 5.0 & - & - & - & - & 6.3 & 7.0 \\
\hline M 27 & 335 & 598 & 487 & 970 & 283 & 580 & 310 & 423 & 1.0 & 1.0 & - & - & - & - & 5.7 & 5.0 \\
\hline LSD $(5 \%)$ & 100 & - & 112 & - & 156 & - & 174 & - & 0.9 & 1.4 & - & - & - & - & 0.8 & 1.8 \\
\hline \multicolumn{17}{|l|}{ Slicing type } \\
\hline Dasher II & 713 & 1,048 & 572 & 972 & 780 & 1,097 & 1,197 & 1,567 & 1.0 & 2.0 & - & - & - & - & 3.0 & 4.0 \\
\hline Cherokee & 697 & 1,052 & 548 & 1,085 & 770 & 1,437 & 1,217 & 1,513 & 1.0 & 2.0 & - & - & - & - & 3.0 & 6.0 \\
\hline Marketmore 76 & 555 & 1,046 & 438 & 1,137 & 623 & 1,302 & 1,110 & 1,457 & 1.0 & 4.0 & - & - & - & - & 3.5 & 4.0 \\
\hline Spacemaster & 520 & 993 & 305 & 794 & 663 & 1,098 & 1,077 & 1,467 & 4.3 & 4.0 & - & - & - & - & 5.5 & 7.0 \\
\hline Bush Champion & 442 & 782 & 280 & 613 & 430 & 775 & 623 & 850 & 5.5 & 3.0 & - & - & - & - & 5.0 & 7.0 \\
\hline Bush Whopper II & 450 & 917 & 479 & 903 & 343 & 1,037 & - & - & 1.0 & 1.0 & - & - & - & - & 3.8 & - \\
\hline $\operatorname{LSD}(5 \%)$ & 100 & - & 112 & - & 156 & - & 174 & - & 0.9 & 1.7 & - & - & - & - & 0.8 & 1.5 \\
\hline Correlation $^{\mathrm{v}}$ & \multicolumn{4}{|c|}{$0.22 \mathrm{NS}$} & \multicolumn{4}{|c|}{$0.66^{*}$} & \multicolumn{4}{|c|}{$0.74 * *$} & \multicolumn{4}{|c|}{$0.66^{*}$} \\
\hline
\end{tabular}

LSD $=$ least significant difference.

${ }^{\mathrm{z}}$ Vine length in $\mathrm{mm}$ at harvest 1.

${ }^{\mathrm{y}}$ Vine length in $\mathrm{mm}$ at harvest 8 .

${ }^{\mathrm{x}}$ Values for patio trial.

${ }^{\mathrm{w}}$ Values for field trial.

${ }^{\mathrm{v}}$ Correlation between patio and field data for spring and summer trials. Significance is indicated by $*(P=0.05), * *(P=0.01)$, or NS $($ nonsignificant $)$. 
evaluated. There were significant correlations between patio and field for total yield $(r=0.93)$, early yield $(r=0.73)$, and PM rating $(r=0.74)$. There were no significant strong $(r \geq 0.60)$ correlations among traits in the patio trial (Table 7).

\section{Discussion}

Urban gardening has increased in popularity since the early 2000 s as communities have embraced the local food movement. Gardeners are interested in cultivars that maximize yield and quality, while minimizing requirement for space. For cucumbers, most cultivars have a vining growth habit or concentrated harvest, characteristics undesirable to home gardeners. In this study, two dwarf-determinate cultivars 'NC-Danbury' and 'Spacemaster' were among the top six yielders. Neither was among the earliest to harvest because of their monoecious flowering habit. However, if the three gynoecious cultivars were excluded, four of the remaining early cultigens were dwarf-determinate type (M $27 \times$ NC-25, NC-25, Picklebush, and Spacemaster). The dwarf-determinate cultigen NC-26 was among the top cultigens with the highest percentage of marketable fruit. The dwarf-determinate cultivars Picklebush,
Bush Champion, and Spacemaster were highly susceptible to PM in the spring season. Those same cultivars plus M 27 were also susceptible to DM in the summer season. In this study, dwarf cucumber types performed as well as tall-indeterminate (vining) type.

Besides yield, fruit quality is important to consider. For home gardeners, LD ratio is less important than for commercial growers, but it may be used to compare fruit size among cultivars. Generally, pickling type cucumbers have a smaller LD ratio than slicing types. In this study, the smallest slicing type was longer than the longest pickling type. Firmness is an important trait

Table 6. Yield, marketable fruit, and gynoecious rating for spring and summer patio (three plants/pot planting density) and field trials for 14 cucumber cultivars.

\begin{tabular}{|c|c|c|c|c|c|c|c|c|c|c|c|c|c|c|c|c|}
\hline & \multicolumn{4}{|c|}{ Total yield $^{\mathrm{z}}\left(\mathrm{g} /\right.$ pot or $\left.\mathrm{Mg} \cdot \mathrm{ha}^{-1}\right)$} & \multicolumn{4}{|c|}{ Early yield ${ }^{y}(\mathrm{~g}$ or $\mathrm{Mg})$} & \multicolumn{4}{|c|}{ Marketable fruit } & \multicolumn{4}{|c|}{ Gynoecious rating inde ${ }^{x}$} \\
\hline & \multicolumn{2}{|c|}{ Spring } & \multicolumn{2}{|c|}{ Summer } & \multicolumn{2}{|c|}{ Spring } & \multicolumn{2}{|c|}{ Summer } & \multicolumn{2}{|c|}{ Spring } & \multicolumn{2}{|c|}{ Summer } & \multicolumn{2}{|c|}{ Spring } & \multicolumn{2}{|c|}{ Summer } \\
\hline \multicolumn{17}{|l|}{ Pickling type } \\
\hline M $27 \times \mathrm{NC}-25$ & 2,404 & 55.9 & 816 & 13.0 & 507 & 10.6 & 370 & 6.8 & 91 & 91 & 59 & 62 & 3.7 & 6 & 6 & 4 \\
\hline $\mathrm{NC}-25$ & 1,671 & 42.3 & 896 & 11.9 & 552 & 8.9 & 374 & 6.4 & 85 & 79 & 64 & 48 & 3.8 & 7 & 5 & 4 \\
\hline M 27 & 1,792 & 26.4 & 688 & 1.4 & 348 & 1.1 & 265 & 0.7 & 82 & 87 & 60 & 20 & 4.3 & 4 & 4 & 2 \\
\hline NC-74 & 2,397 & 33.1 & 517 & 11.9 & 650 & 5.1 & 145 & 5.4 & 93 & 94 & 90 & 63 & 3.8 & 4 & 4 & 4 \\
\hline Vlaspik & 2,820 & 64.3 & 1,198 & 15.9 & 885 & 15.6 & 535 & 9.5 & 95 & 81 & 70 & 54 & 8.2 & 9 & 8 & 5 \\
\hline $\operatorname{LSD}(5 \%)$ & 586 & 14.6 & 253 & 7.8 & 199 & $?$ & 153 & $?$ & 9 & ? & 20 & ? & 1.4 & 2 & 1 & 2 \\
\hline \multicolumn{17}{|l|}{ Slicing type } \\
\hline Bush Champion & 2,253 & 50.3 & 91 & 2.4 & 401 & 6.6 & 0 & 0.5 & 80 & 82 & 0 & 363 & 3.5 & 5 & 1 & 4 \\
\hline Bush Whopper II & 1,996 & 25.2 & 688 & - & 378 & 0 & 189 & - & 93 & 82 & 73 & - & 4.3 & 3 & 5 & - \\
\hline Cherokee & 2,661 & 65.5 & 896 & 15 & 771 & 24.9 & 408 & 9.9 & 78 & 84 & 68 & 42 & 5.8 & 4 & 6 & 5 \\
\hline Dasher II & 2,555 & 63.6 & 998 & 17.2 & 794 & 19.4 & 287 & 12.3 & 80 & 92 & 72 & 71 & 7.0 & 7.0 & 7 & 6 \\
\hline
\end{tabular}

LSD $=$ least significant difference.

${ }^{\mathrm{z}}$ Total yield measured as $\mathrm{g} /$ pot for patio trial using a $12 \mathrm{~L}$ container with three plants and $\mathrm{Mg} \cdot \mathrm{ha}^{-1}$ for field trial.

${ }^{\mathrm{y}}$ Combined yield for the first three harvests measured as $\mathrm{g} /$ pot for patio trial using a $12 \mathrm{~L}$ container and $\mathrm{Mg} \cdot \mathrm{ha}^{-1}$ for field trial.

${ }^{\mathrm{x}}$ Gynoecious rating based on a 1 to 9 scale $(1=$ androecious, 2 to $3=$ andromonoecious, 4 to $6=$ monoecious, 7 to $8=$ predominately gynoecious, $9=$ gynoecious $)$.

${ }^{\mathrm{w}}$ Values for patio trial.

${ }^{\mathrm{v}}$ Values for field trial.

${ }^{\mathrm{u}}$ Correlation between patio and field data for spring and summer trials. Significance is indicated by a $*(P=0.05),{ }^{* *}(P=0.01)$, or Ns (nonsignificant).

Table 7. Pearson's correlation coefficient of plant traits evaluated for 14 cucumber cultivars in two seasons in patio trials.

\begin{tabular}{|c|c|c|c|c|c|c|c|c|c|c|c|}
\hline & Density $^{z}$ & VL $(\mathrm{H} 1)^{\mathrm{y}}$ & $\operatorname{VL}(\mathrm{H} 8)^{\mathrm{x}}$ & Gyn.R." & $\mathrm{PM}^{\mathrm{v}}$ & $\mathrm{DM}^{\mathrm{u}}$ & Total yield & Early yield $^{t}$ & Marketable & Cull $^{\mathrm{r}}$ & E.Mark. ${ }^{\mathrm{q}}$ \\
\hline$\overline{\mathrm{VL}}(\mathrm{H} 1)$ & 0.0114 & & & & & & & & & & \\
\hline Gyn.R. & 0.0152 & $0.1702 * * *$ & $0.1328^{* * *}$ & & & & & & & & \\
\hline PM & 0.1066 & $-0.2822 * * *$ & $-0.2719 * * *$ & -0.0287 & & & & & & & \\
\hline Total yield & $0.3234 * * *$ & $0.4615^{* * *}$ & $0.2257 * * *$ & $0.1328 * * *$ & $0.2481 * * *$ & $-0.4638 * * *$ & & & & & \\
\hline Early yield & $0.2566 * * *$ & $0.5165^{* * *}$ & 0.0852 & $0.3199 * * *$ & 0.09493 & $-0.2066^{* * *}$ & $0.6736^{* * *}$ & & & & \\
\hline Market. & $0.2948 * * *$ & $0.4430 * * *$ & $0.2280^{* * *}$ & 0.0738 & $0.1703 * * *$ & $-0.4875^{* * *}$ & $0.9683 * * *$ & $0.6552 * * *$ & & & \\
\hline$\%$ Mark. ${ }^{p}$ & 0.04801 & $0.2991 * * *$ & $0.22973 * * *$ & -0.0357 & $-0.1678 * * *$ & $-0.4158 * * *$ & $0.4954 * * *$ & $0.3840 * * *$ & $0.6310^{* * *}$ & $-0.3830 * * *$ & $0.5070^{* * *}$ \\
\hline
\end{tabular}

LSD $=$ least significant difference.

${ }^{2}$ Planting density.

${ }^{\mathrm{y}}$ Vine length (mm) at Harvest 1.

${ }^{\mathrm{x}}$ Vine length $(\mathrm{mm})$ at Harvest 8.

${ }^{\mathrm{w}}$ Gynoecious rating ( 1 to $9,1=$ androecious, $5=$ monoecious, $9=$ gynoecious $)$.

'Powdery mildew rating ( 0 to $9,0=$ none, $9=$ plant killed).

uDowny mildew rating ( 0 to $9,0=$ none, $9=$ plant killed $)$.

${ }^{\mathrm{t}}$ Combined marketable yield for the first three harvests.

${ }^{\mathrm{s}}$ Marketable yield.

${ }^{\mathrm{r}}$ Yield of cull (crooked and nubbin) fruit.

${ }^{\mathrm{q}}$ Marketable yield from the first three harvests.

${ }^{\mathrm{p}}$ Percentage marketable yield.

Significant values are indicated as * $(P=0.05), * *(P=0.01)$, or *** $(P \leq 0.001)$. 
for pickling types as firm fruit make better pickles. Firmness was measured only on pickling cucumbers in this study.

In terms of early yield 'Vlaspik' and 'Dasher II' were the best performing cultivars in this study. Both had high total yield, high early yield, and a high percentage of marketable fruit. Both 'Vlaspik' and 'Dasher II' are gynoecious cucumber types. If early yield is needed and a gynoecious type is being grown, then a monoecious type must be planted nearby to ensure fruit set. This is a downside to gynoecious cultivars because many gardeners may not want to deal with pollination issues. A solution for home gardeners is to choose a monoecious type, focusing on cultivars having high yield and early maturity.

For container gardeners not concerned with early yield and more interested in a continuous harvest, the best cultivars in our study were Marketmore 76 (tall, monoecious, slicing type) and NC-Danbury (tallindeterminate, monoecious, pickling type). Both were among the top producers, had a high percentage of marketable fruit, and were moderately resistant to PM and DM.

Many container gardeners prefer to grow dwarf-determinate cultivars because they are easier to fit in a limited space. If a gardener wanted to grow a dwarf cucumber, the best performing cultivars in this study were NC-25 and Spacemaster (monoecious, slicing type). 'NC-25' had high total yield and percent marketable fruit. 'Spacemaster' had high total yield but was susceptible to PM and DM. If a gardener would rather choose a tall type, the best performing tall pickling type in this study was 'Vlaspik'. The best tall slicing types were 'Dasher II' and 'Marketmore 76'. All the cultivars suggested earlier had high quality ratings. The pickling types suggested had acceptable firmness measurements.

Based on the results of this study, the best time to plant container cucumbers is in the spring. The highest marketable yield of the spring and summer trials differed significantly. Some of this was due to the high incidence of $\mathrm{DM}$ and to the higher temperatures during the summer. Generally spring is a better time to plant cucumbers as disease and temperature stress is reduced during this time.

Highest marketable yield was obtained using three plants per $12 \mathrm{~L}$ container rather than one or two for some of the cultivars. Although cucumbers appear to grow well with $4 \mathrm{~L}$ of soil volume per plant, optimal production will vary by cultivar. Because we only tested three densities, it cannot be concluded that three plants per $12 \mathrm{~L}$ container is the best density to grow cucumbers as we did not test higher densities such as four or five plants per $12 \mathrm{~L}$ pot or larger pots, which could have possibly resulted in a better yield.

The correlations between patio and field trials for total yield, early yield, and PM suggest that cucumber performance in the containers could be predicted using data from field trials. This allows home gardeners to use trial results from extension leaflets and trial summaries intended for commercial producers in their area to choose cultivars for use in their container garden. There were no strong correlations among traits in the patio trial. Thus, it may not be possible to measure fewer traits as each trial appears to measure a separate aspect of cultivar performance.

Because this study did not include all possible cultivars, specific cultivar recommendations cannot be made. Instead, based on our findings in this study, we recommend that cucumber cultivars with specific qualities be used in containers to obtain the best performance. Whether grown in soil beds or containers, cucumber cultivars should have the following traits: high yield, early maturity, high fruit quality (high percentage of marketable fruit), and disease resistance. In addition, when grown in a container, the cultivar should also have the following traits: dwarf growth habit, pickling type (no need for peeling), and monoecious type (no pollinizer required). The cultivars in this study that had those specific traits were NC-74, NC-25, M $27 \times$ NC-25, and Bush Whopper II.

\section{Literature Cited}

Adams, M. and L.M. Quesada-Ocampo. 2015. Cucurbit powdery mildew fact sheet. North Carolina State Univ. Coop. Ext., Cary, NC. Dec. 2017. <https://content.ces.ncsu.edu/cucurbitpowdery-mildew $>$.

Bass, L. 1999. Container vegetable gardening. North Carolina Coop. Ext. Serv., Raleigh, NC. Dec. 2017. <https://content.ces.ncsu. edu/container-vegetable-gardening $>$.

Colasanti, K.J.A., M.W. Hamm, and C.M. Litjens. 2012. The city as an "Agricultural powerhouse"? Perspectives on expanding urban agriculture from Detroit Michigan. Urban Geogr. 33:348-369.

Crandall, C. and B. Crandall. 1996. Planters, containers, \& raised beds. Sterling Publishing Co., Inc., New York, NY.

Demboski, K., A. Swanberg, and J.C. Martin. 2001. Container vegetable gardening. Ohio State Univ. Ext. Fact Sheet, Columbus, OH. $<$ www.ohioline.osu.edu/hyg-fact/1000/1647. html>.

Freeman, C., K.J.M. Dickinson, S. Porter, and Y. van Heezik. 2012. My garden is an expression of me: Exploring householders' relationships with their gardens. J. Environ. Psychol. 32:135-143.

Harlan, J.R. 1975. Crops and man. Amer. Soc. Agron., Madison, WI.

Harrison, H.C. 1996. Container gardening. Univ. Wisconsin-Ext. Lflt. A3382. <http://www1. uwex.edu/ces/pubs>.

Holmes, G.J. and J.M. Kemble. 2009. Vegetable Crop Handbook. SEVEW Group, Vance Publishing Corp., Lincolnshire, IL.

Hopkins, K., D. Coffin, F. Wertheim, and C. Bowie. 2008. Bulletin \#2762 growing vegetables in container gardens. Univ. Maine, Orono, ME. <http://umaine.edu/publications/2762e/>.

Hunter, M.C.R. and D.G. Brown. 2012. Spatial contagion: gardening along the street in residential neighborhoods. Landscape and Urban Planning 105:405-416.

Mason, S.C., T.W. Starman, R.D. Lineberger, and B.K. Behe. 2008. Consumer preference for price, color harmony and care information of container gardens. HortScience 43:380-384.

Ojiambo, P.S., D.H. Gent, L.M. Quesada-Ocampo, M.K. Hausbeck, and G. Holmes. 2015. Epidemiology and population biology of Pseudoperonospora cubensis: A model system for management of downy mildews. Annu. Rev. Phytopathol. 53:223-246.

Sanders, D.C. 1997. Vegetable crop irrigation. North Carolina State Univ. Coop. Ext. Serv., Raleigh, NC. <http://www.ces.ncsu.edu/depts/ hort/hil/hil-33-e.html>.

Sanders, D.C. 2004. Vegetable crop guidelines for the Southeastern U.S. 2004-2005. North Carolina Veg. Growers Assn., Raleigh, NC.

SAS Institute. 2005. SAS/STAT user's guide, release 9.1 edition. SAS Institute Inc., Cary, NC.

Statista GmbH. 2017. Statista: The statistics portal. Statista, Hamburg, Germany. Aug. 2017. $<$ https://www.statista.com/statistics/257324/ per-capita-consumption-of-fresh-cucumbersin-the-us/>.

U.S. Department of Agriculture. 2005. Agricultural statistics. U.S. Dept. Agr., Natl. Agr. Stat. Serv., Washington, DC. <http://www.usda. gov/nass/pubs/agr05/05_ch4.PDF>.

U.S. Department of Agriculture. 2016. United States standards for grades of cucumbers. USDA, Agr. Mktg. Serv., Washington, DC. $<$ https://www.ams.usda.gov/sites/default/files/ media/CucumberStandards.pdf $>$.

Wehner, T.C. 1989. Breeding for improved yield in cucumber, p. 323-359. In: J. Janick (ed.). Plant breeding reviews. Vol. 6. Timber Press (John Wiley \& Sons), Hoboken, NJ.

Wehner, T.C. and C.H. Miller. 1985. Effect of gynoecious expression on yield and earliness of a fresh-market cucumber hybrid. J. Amer. Soc. Hort. Sci. 110:464-466.

Whiting, D., C. O'Meara, and C. Wilson. 2014. Vegetable gardening in containers. Colorado State University Master Gardener's Program Garden Notes, Boulder, CO. <http://www.ext. colostate.edu/mg/Gardennotes/724.html $>$. 